Commentary

\title{
Equal Access to Make Emergency Calls: A Case for Equal Rights for Deaf Citizens in Norway and Sweden
}

\author{
Camilla Warnicke \\ University Health Care Research Centre, Örebro University, 70281 Örebro, Sweden; E-Mail: camilla.warnicke@oru.se
}

Submitted: 1 June 2018 | Accepted: 24 September 2018 | Published: 31 January 2019

\begin{abstract}
It is stipulated that deaf citizens have equal right to use social services as other citizens. One social service is the access to make an emergency call. Deaf citizens who cannot hear and use a signed language to communicate have to make emergency calls in another way rather than relying on listening and speaking via a telephone. However, the possible ways to call are not the same for deaf citizens in all countries. This commentary shows that there are options dedicated for deaf citizens to make emergency alarms in both Norway and Sweden: via telephone typewriters, Short Message Service, and Video Relay Service, although the design of the respective options differs between the countries. However, it is argued that deaf citizens in Norway do not have equal access to make emergency alarms as other citizens in Norway, whereas the situation for deaf citizens in Sweden may be seen as equal compared to other citizens in Sweden, although there still are limitations.
\end{abstract}

\section{Keywords}

alarm call; deaf; equal rights; interpreter; Short Message Service; signed language; SOS phone; telephone typewriters; Video Relay Service

\section{Issue}

This commentary is part of the issue "People with Disabilities: The Overlooked Consumers", edited by Anita Borch and Kirsi Laitala (Consumption Research Norway-SIFO, Norway).

(C) 2019 by the author; licensee Cogitatio (Lisbon, Portugal). This article is licensed under a Creative Commons Attribution 4.0 International License (CC BY).

\section{Introduction}

It is stipulated that deaf citizens have rights equal to other citizens. This stipulation can be found in the United Nations document Conventions on the Rights for Persons with Disabilities (United Nations, 2006). Citizens' rights are specified in The United Nations Universal Declaration of Human Rights (United Nations, 1948). Both documents emphasize that all citizens are entitled to equal protection against discrimination, which includes social and cultural rights, as well as protection against language discrimination. Likewise, denial of social rights is prohibited by the European Commission in The European Accessibility Act (European Commission, 2015) and The European Disability Strategy 2010-2020 (European Commission, 2010), where common accessibility requirements for social services is emphasized. Although there are several documents declaring equal rights for all, barriers still exist, such as a lack of provision of service, problems with service delivery and a lack of accessibility for people with disabilities (World Health Organization \& World Bank, 2011).

One social service is to provide facilities to make an emergency alarm and call for help to an emergency dispatch centre since access to emergency services can be seen as a right for all citizens (see Paredes, Fonseca, Cabo, Pereira, \& Fernandes, 2014). However, to make an alarm call assumes that you have access to, and can use, the existing services (cf. Chiu, Liu, Hsieh, \& Li, 2010; Constantinou, loannou, \& Diaz, 2017; Power, Power, \& Horstmanshof, 2006). However, compared to a telephone call to make an alarm by auditive and vocal resources, this may be done in another way for deaf people who use a signed language. In this commentary, an ongoing activity in real time by signed and/or spoken language is referred to as to make a call. Whereas to make 
an alarm, is an activity that is done by text exchanges and/or not in real time.

The possibility for deaf citizens to use social services has changed over time. Likewise, the ways deaf citizens have been treated have also changed over time. Historically, people who are deaf have been considered to be, and have been treated as people who need help from someone who can hear (Fredäng, 2003; Kermit, 2006; Raanes, 2013) who can interpret for them in order for them to take part in society and to communicate with hearing people (Kermit, Mjøen, \& Olsen, 2011; Lundström, 2001). According to these views, those who then interpreted for deaf people did so without remuneration, and it was often a relative, a hearing friend, or helpers from church (Lundström, 2001; Roy, 2002). Hence, deaf people were dependent on someone who could hear and who was willing to make sacrifices for them. Consequently, at that time, the only way for deaf people to make an emergency alarm was to depend on others. These limitations to make an alarm to an emergency dispatch centre show that deaf people historically have not had the same civic opportunities as other citizens.

Today, deaf people have access to call as a citizen's right in both Norway and Sweden (Haualand, 2011). However, even though these countries are geographically close, the solutions available to deaf people to make emergency alarms differs. Moreover, the national organization of emergency dispatch centres are not the same in the two countries. In Norway, there are different alarm numbers depending on the type of alarm (i.e., fire brigade, police, doctor, or ambulance), whereas Sweden, as a member of the European Union (EU), follows a stated standard where one centre in the country allocates the emergency dispatch centre (see European Emergency Number Association, 2018). Consequently, in Sweden, SOS Alarm is responsible for allocating all such resources.

\subsection{Ways to Communicate: Signed, Spoken and Written Languages}

According to deaf people, to speak and listen through a telephone is not optimal if they cannot hear. Therefore, deaf people may use other solutions to make phone calls if their preferable first language of communication is a signed language. Compared to people who hear and have another spoken language than the majority language, hearing people could make an emergency call by the use of a "bridge language" (i.e., a lingua franca), for example English, in Norway and Sweden, or they may communicate by using some simple words in negotiation. People living in a foreign country can probably also learn the majority language over time. However, people who are deaf cannot learn to hear.

Signed and spoken languages differ: signed languages are visual/gestural languages, whereas spoken languages are aural/oral languages. Many spoken lan- guages have a written form, which signed languages such as Swedish Sign language (SSL) and Norwegian Sign language (NSL) do not have in the same way (see for example Grushkin, 2017; Hole, 2007; Regeringskansliet, 2006). Thus, it can be challenging for deaf people to read and write written language (Regeringskansliet, 2006) in an urgent situation. However, in signed languages, some spoken words, for example addresses, names and other words, may instead be finger spelled letter by letter.

The modalities of signed and spoken languages also rely on different grammar features, which means that signs cannot simply be transformed into spoken words (Bergman \& Nilsson, 1999; Regjeringa, 2008). Adding to this, signed languages, as every other language, have cultural aspects. The cultural aspects of signed language include the way it is performed and accepted in society. When comparing the acceptance of NSL in Norway and SSL in Sweden it becomes apparent that both countries protect their respective signed language by law. In the case of Norway, NSL was accepted and recognized as a full language in 2008. Norwegian law stipulated that NSL deserved a higher official status, and the language should be supported for persons who use NSL (Regjeringa, 2008). In the case of Sweden, SSL is protected by the Swedish language law, which states that people who are deaf should have the possibility to use SSL (Svensk författningssamling, 2009). Moreover, the public has a special responsibility to protect and promote SSL. In 1981, the government acknowledged SSL as (preferably) the first language of deaf people in Sweden, whereas spoken and written Swedish can be a second language (Regeringskansliet, 2006).

\section{Options for Deaf Citizens to Make Emergency Alarms}

Many countries all over the world, including Norway and Sweden, have regular emergency dispatch centres. However, the options for deaf citizens to get in contact with an emergency dispatch centre differ from citizens who use spoken languages and call by an ordinary telephone when making an emergency alarm. Deaf citizens require other solutions to make emergency alarms.

\subsection{Making an Emergency Alarm by Telephone Typewriter}

Deaf people can communicate from a distance using text, which can be done with a telephone typewriter (TTY) by exchanging text in real time. The exchange is organized via texted instructions by signalling "go ahead" and "over and out", in other words, the communication is structured and is not simultaneous, as in face-to-face interaction. Although TTY can be used to make emergency alarms in both Norway and Sweden, there are radical differences in their design.

In the case of Norway, deaf citizens can use TTY to make emergency alarms, though it must to be done through a Text Relay Service where an operator relays the 
written text from the deaf person to the emergency dispatch operator, and vice versa, via a special alarm number (Call-It, 2018; Telenor, 2018). In Sweden, deaf citizens can make an alarm call directly to the emergency dispatch operator via a special number using TTY (SOS Alarm, 2017).

However, one drawback of making an alarm through TTY is the aspect of time, as it is an urgent situation (Forslund, Kihlgren, \& Kihlgren, 2004). Additionally, since written text is not a deaf person's first language, it may be cumbersome to write an urgent message in a precarious situation (cf. Chan et al., 2010, p. 137). Findings from emergency calls to the Swedish emergency dispatch centre also show a risk of misinterpretation when people use a foreign language, and also when there are cultural differences that operators may not understand (Forslund et al., 2004). Alarms from a TTY to an emergency dispatch centre could also be challenging because the information conveyed may be "meagre" (Forslund et al., 2004), so it may be difficult for the operator at the emergency dispatch centre to decode what is written. Thus, TTY may be used in acute situations, but the messages will be short, unsecure, and time consuming. Above all, there is the question of whether deaf people use TTY to communicate from a distance at all, since presumably few deaf citizens neither have a stationary TTY nor have downloaded the TTY application on their mobile or smart phone.

\subsection{Making an Emergency Alarm by Short Message Service}

With the influence of a more digitalized and mobile society, deaf citizens in both Norway and Sweden can make an emergency alarm by a sending a short message service (SMS) from a mobile phone or a smart phone to an emergency dispatch centre. In Norway, a pilot project has been launched offering participation to deaf citizens (Direktoratet for samfunnssikkerhet og beredskap, 2018). The project runs officially until 2019, but has not yet been evaluated (Direktoratet for samfunnssikkerhet og beredskap, 2016). In Sweden, the option to make an emergency alarm by SMS has been available since 2012 . However, as is the case in both Norway and Sweden, deaf citizens must register their mobile phone with the national emergency dispatch centre beforehand (Direktoratet for samfunnssikkerhet og beredskap, 2018; SOS Alarm, 2017).

Some of the barriers that occur when using TTY are also relevant when making an alarm via SMS; written language may be challenging to write and read in urgent situations, and the messages are short and may be meagre. Another issue when using the SMS service is that citizens must have money on their phone and also coverage in the case of Norway (Direktoratet for samfunnssikkerhet og beredskap, 2018). Additionally, both the Norwegian and the Swedish emergency services note a similar issue: the SMS may be delayed or disappear if coverage from a network operator is poor (Direktoratet for sam- funnssikkerhet og beredskap, 2018; SOS Alarm, 2017). Therefore, the service provider in Sweden recommends that SMS may be used by deaf people only if they cannot get help from someone with "full speech and hearing ability" (authors translation from SOS Alarm, 2017). This recommendation indicates that it is not safe to use SMS to make emergency alarms and that it is preferable for deaf people to get assistance from a person who can hear if they need to call for help, which means reverting to historical and unsatisfactory solutions.

\subsection{Making an Emergency Call by Video Relay Service}

To communicate and make an emergency alarm using signed language is possible via a video phone through Video Relay Service (VRS). In cases of emergency, the VRS call is relayed by an interpreter who interprets between the deaf person and the operator at an emergency dispatch centre. The interpreter is able to see the person using a video phone on a screen and to hear the person using a telephone via a head set (Warnicke \& Plejert, 2018). In some calls, a text exchange may also be possible between the caller from a video phone and the interpreter, i.e., a "total conversation". However, this option is dependent on the caller's video phone resources. VRS, however, is an option for deaf people that allows them to make a call by signed language in real time.

For signing deaf people in Norway, VRS calls have been an option since 2008 (Arbeids- og velferdsetaten, 2018b), and are available Monday through Friday, between 8 am and $8 \mathrm{pm}$. (Arbeids- og velferdsetaten, 2018a). In Sweden, VRS has been a regular service 1996 and is open around-the-clock (Warnicke, 2017). The Swedish VRS offers a special number for emergency calls (Bildtelefoni.net, 2018), unlike in Norway. Calling through a special emergency number, as is possible in Sweden, reduces the time spent waiting on hold. It also supports the VRS interpreter; when answering the call he/she already knows that it is an SOS call (cf. Warnicke \& Plejert, 2012, 2016).

Even though deaf people can call using a signed language through VRS, there are challenges. One challenge is that the interpreter needs to manage the fact that both the deaf person and the emergency dispatch operator are physically separated and are located in different places. The interpreter thus has to manage several practical matters because of the lack of direct contact between the caller and the emergency dispatch operator, for example the organization of turns (Warnicke \& Plejert, 2012). Therefore, organization also takes time since the interpreter needs to see what is signed before formulating and interpreting what is said, i.e., processing time in order to formulate and make the interpreting (Warnicke, 2018). To decode what is signed is a challenge, as the signed language is communicated through a flat screen on video phone which means that the media is two-dimensional instead of three-dimensional as in faceto-face communication. Thus, to decode a finger spelled 
word, for example an address or a name, is difficult and probably even more difficult in an emergency call when the situation is urgent and stressful. Furthermore, decoding can be demanding depending on the screenshot between the signing caller and the interpreter, which is affected by the surroundings the deaf party is calling from. When the surroundings or the connection are poor, the screen may be pixelated, which means that the ability to interpret is affected (Warnicke \& Plejert, 2012). Hence, the organization of turns and the restricted view of the caller may be challenging for both the interpreter as well as for the deaf person. The person at the emergency dispatch centre may also be affected by these circumstances, which can lead to difficulties in understanding what the call concerns (cf. Forslund et al., 2004; Warnicke \& Plejert, 2016)

Communication among deaf people via video phone observes a discourse organization that differs from a telephone call (Keating \& Mirus, 2003); for instance, some information is not said because the video phone gives visual access to what is happening on the other end. In calls via VRS, there might be a discrepancy between what needs to be said and what is happening in the area around the deaf person. For example, a deaf person calling from a fire could be stressed and the surroundings could make visual contact between the deaf person and the interpreter challenging, so it would be hard for the interpreter to see what the deaf person is signing. Since the interpreter should just interpret and the operator at an emergency dispatch centre should assess what is needed, these circumstances may be precarious and possibly life threatening. To conclude, it is generally challenging for an interpreter to decode signed language from a two-dimensional screen and it can be even more difficult in urgent calls.

\subsection{Solutions of Yesterday and for Tomorrow(?): REACH112 a Completed Pilot Project in Sweden}

Sweden, as a member of the EU, has participated in a pilot project called REsponding to All Citizens needing Help: REACH112 (European Emergency Number Association, 2012). The project was funded by the EU organization European Emergency Number Association. The project was run between 2009 and 2012 in Sweden and tested a total conversation, i.e., a combination of live real-time text, video and voice simultaneously to make emergency calls. The calls provided visual contact between all of the physically separated interlocutors: the help-seeking party, the remote Swedish/SSL interpreter, and the operator at the emergency dispatch centre. Outcomes of the project stress a "huge social change in the target user group", and "enormous benefits in terms of health, employability and social interaction" (European Emergency Number Association, 2012, p. 27), although it may be a question of how to sustain the services in the light of cuts from the respective central government. However, after the project was finished, this solution was not imple- mented as a regular service. Nevertheless, the EU is still working to integrate IP-based communication technologies and interoperability within the project "NEXt generation Emergency Services", although aspects of making emergency calls by signed language as such are not an issue (see Nexes, 2018).

\section{Do Deaf Citizen Have Equal Access to Give an Alarm as Other Citizens?}

For a deaf person to be able to make an alarm, solutions designed for signing deaf persons are needed (such as TTY, SMS and video phone), and the emergency dispatch centre must be able to handle these solutions. Thus, the issue involves telecom access as such (cf. Paredes et al., 2014). Regarding the available telecom access for deaf citizens in Norway and Sweden, there are options available in both countries. These options may look the same on the surface, but they differ according to the design of the technical solutions and their availability and the structural organization of the emergency service within the countries also differ.

Making an emergency alarm using text (i.e., TTY and SMS) is an option for deaf citizens. In Norway, the TTY emergency alarm needs to go through a Text Relay Service and not, as in Sweden, directly to the emergency dispatch centre. Thus, emergency dispatch centres in Norway do not provide a direct link between the caller and the emergency operator. In Sweden, an operator at the emergency dispatch centre handles the call without an intermediator. Nonetheless, in both countries, it is possible to make emergency alarms via TTY around the clock. Another available option using text, in both countries is to send an SMS. Of course, it can be important for deaf citizens to have the possibility to make emergency alarms by text, but this option is not optimal because of the challenges with giving alarms using written text.

An equal way for deaf people to make an emergency call is for them to be able to use signed language. However, the only way deaf people in Norway can make an emergency call using signed language is via VRS, Monday to Friday, between 8 am and $8 \mathrm{pm}$. Adding to this, calling via VRS in Norway is done via a regular number, so the call may be placed in line and put on hold. Since time is restricted and the call is handled as an average call, the option to make an emergency call at whatever time needed is not equal to other citizens in Norway. In Sweden, it is an option to call using signed language via the Swedish VRS is offered around the clock. It is also an option in Sweden to call via a special number to get in contact with the emergency dispatch centre immediately. Although the VRS services in the two countries are similar on the surface, variations within the organizations show radical differences in terms of deaf peoples' equality to other citizens. Both Norway and Sweden have different telecom access options for deaf citizens to make emergency alarms. The structures of the options do not create equality for deaf citizens in Norway, whereas the sit- 
uation in Sweden is more developed, since it has a different design.

Nevertheless, there are also challenges with the Swedish VRS. In the Swedish VRS, as well as the Norwegian VRS, the deaf caller and the emergency dispatch operator lack visual contact. Visual access in emergency calls by deaf citizens can facilitate the call, and even if the operator at the emergency dispatch centre cannot understand what is signed or even understand signed language at all, the operator may get an indication of what is happening by seeing the surroundings. Through the emergency dispatch operator's greater knowledge and observation, he/she could possibly make a more correct assessment of the situation. Thus, visual contact between the deaf person, the interpreter and the emergency dispatch operator will provide a more efficient communication. As stated earlier, there are difficulties for the interpreter in decoding signed language on a twodimensional video phone, and especially in a stressful situation. The possibility for everyone to see each other may also help the interpreter to focus on the interpreting itself and not the surrounding meta-information (see Warnicke, 2018; Warnicke \& Plejert, 2012, 2016). Since every second counts, more efficient communication and interpretation can save lives. Although both the telecom access and emergency dispatch service seem to be able to manage visual contact between the interpreter and the emergency dispatch operator in Sweden, as shown in the pilot project REACH112, it is not yet provided as a regular service in Sweden.

Although there are several possibilities and solutions for deaf citizens in both Norway and Sweden based on telecom access to make emergency alarms, emergency dispatch services need to be able to manage those alarms if full equality is to be realized. In this aspect, emergency dispatch services need to offer direct communication by signed language. One solution towards the possible path to full equality is a total conversation solution, as in the REACH112-project. A total conversation solution could even be offered as a possibility for everyone, and if so, visual contact in emergency calls would not only be an advantage for deaf citizens but for everybody as a universalistic view of human functioning (cf. Jarl \& Lundqvist, 2018) and to eliminate the lack of visual contact in all alarm calls.

\section{Conclusions}

This commentary shows that deaf citizens can make emergency alarms in both Norway and Sweden using solutions such as TTY, SMS, and VRS. However, there are differences in the solutions provided between the two countries in terms of the design, availability and structural organization of the service facility.

In Norway, deaf citizens are restricted to making emergency calls using their first language, NSL, via VRS from Monday through Friday, 8 am to 8 pm, using an ordinary number and may be placed in line and put on hold.
Using written language to make an alarm is possible with TTY via an intermediator and there is a pilot project running in Norway where deaf citizens can make emergency alarms by sending SMS. However, the caller needs to have money on their phone for the SMS, and the service provider has issued a warning that there are coverage limitations. Thus, although deaf citizens have equal rights according to stipulated documents (see Regjeringa, 2008; United Nations, 1948, 2006) the conclusion is that signing deaf citizens in Norway do not have equally access to make emergency alarms as other citizens in Norway.

In Sweden, deaf citizens can call in their first language, SSL, around the clock via VRS through a special emergency number. Deaf people in Sweden may also use written language to make an emergency alarm directly to the emergency dispatch centre via TTY or SMS. Deaf people in Sweden have equal rights to make emergency alarms and calls through an interpreter, although the call will be relayed. However, a further step, and a way to overcome barriers when using VRS, may be if the emergency dispatch centre operator could also see the deaf person, so that all three interlocutors have visual and auditive contact. If all the interlocutors had direct access to each other, the interpreter's work and the operator's intervention decisions could be more strongly supported. Moreover, visual contact among all interlocutors in a call may be beneficial during emergency calls from anyone. However, full equality for deaf signing people in Sweden would be if deaf people could make an emergency call using SSL directly to an emergency dispatch operator who uses SSL as well. This is not possible today so although the situation for deaf signing people in Sweden may be seen as equal, there still are limitations.

\section{Acknowledgements}

I would like to thank Dr. Hilde Haualand, Oslo and Akershus University College of Applied Sciences, Norway, for correspondence regarding the manuscript. I would also like to thank Marie Tapper, Örebro University, Sweden, who generously commented on the text, with great enthusiasm. The current commentary was funded by the University Health Care Research Center, Region Örebro County, Sweden.

\section{Conflicts of Interests}

The author declares no conflict of interests.

\section{References}

Arbeids- og velferdsetaten. (2018a). Bildetolktjenesten [Photo interpreter service]. NAV. Retrieved from www.nav.no/no/Person/Hjelpemidler/Tjenester+og+ produkter/Bildetolktjenesten

Arbeids- og velferdsetaten. (2018b). Bildetolknytt [Photo interpreter Newsletter]. NAV. Retrieved from www.nav.no/no/Person/Hjelpemidler/Tjenester+og+ 
produkter/Bildetolktjenesten/Bildetolknytt

Bergman, B., \& Nilsson, A.-L. (1999). Teckenspråket [Sign language]. In K. Hyltenstam (Ed.), Sveriges sju inhemska språk: Ett minoritetsspråksperspektiv [Sweden's seven native languages: A minority language perspective] (pp. 329-339). Lund: Studentlitteratur.

Bildtelefoni.net. (2018). Bildtelefoni.net: En förmedlingstjänst från PTS [Bildtelefoni.net: A relay service from the Swedish post and telecom agency]. Bildtelefoni.net. Retrieved from http://www. bildtelefoni.net/short-information-in-english

Call-It. (2018). Teksttelefonen 149 og Nødetelefonen 1412 [The telephone typewriter 149 and the emergency phone 1412]. Call-It AS. Retrieved from call-it. no/index.php?option=com_content $\&$ view $=$ article\& id $=3$ \& Itemid $=116$

Chan, Y.-F., Alagappan, K., Rella, J., Bentley, S., SotoGreene, M., \& Martin, M. (2010). Interpreter services in emergency medicine. Journal of Emergency Medicine, 38(2), 133-139.

Chiu, H.-P., Liu, C.-H., Hsieh, C.-L., \& Li, R.-K. (2010). Essential needs and requirements of mobile phones for the deaf. Assistive Technology, 22(3), 172-185.

Constantinou, V., Ioannou, A., \& Diaz, P. (2017). Inclusive access to emergency services: an action research project focused on hearing-impaired citizens. Universal access in the information society, 16(4), 929-937.

Direktoratet for samfunnssikkerhet og beredskap. (2016). Nødnett. Direktoratet for samfunnssikkerhet og beredskap. Retrieved from www.nodnett. no/nyheter/Nyhetsarkiv/Ny-sms-tjeneste-for-doveog-horeselshemmede

Direktoratet for samfunnssikkerhet og beredskap. (2018). Nød-SMS [Emergency-SMS]. Direktoratet for samfunnssikkerhet og beredskap. Retrieved from www.nodsms.no/images/ndsms_brosjyre_fase2_ web.pdf

European Commission. (2010). European Disability 2010-2020: A renewed commitment to a barrierfree Europe. Brussels: European Commission. Retrieved from eur-lex.europa.eu/LexUriServ/LexUri Serv.do?uri=COM:2010:0636:FIN:en:PDF

European Commission. (2015). European accessibility Act. European Commission. Retrieved from ec.europa.eu/social/main.jsp?catld=1202

European Emergency Number Association. (2012). Total conversation \& 112 for all (Publishable Summary REACH112). European Emergency Number Association. Retrieved from cordis.europa. eu/docs/projects/cnect/0/238940/080/reports/001PublishableSummary.pdf

European Emergency Number Association. (2018). EENA. European Emergency Number Association. Retrieved from www.eena.org

Forslund, K., Kihlgren, A., \& Kihlgren, M. (2004). Operators' experiences of emergency calls. Journal of telemedicine and telecare, 10(5), 290-297.

Fredäng, P. (2003). Teckenspråkiga döva: Identitetsförän- dringar $i$ det svenska dövsamhället [Signing deaf: Identity changes in the Swedish Deaf Community]. Stehag: Gondolin.

Grushkin, D. A. (2017). Writing signed languages: What for? What form? American Annals of the Deaf, 161(5), 509-527.

Haualand, H. (2011). Interpreted ideals and relayed rights: Video interpreting services as objects of politics. Disability Studies Quarterly, 31(4).

Hole, R. (2007). Working between languages and cultures: Issues of representation, voice, and authority intensified. Qualitative Inquiry, 13(5), 696-710.

Jarl, G., \& Lundqvist, L.-O. (2018). An alternative perspective on assistive technology: The personenvironment-tool (PET) model. Assistive Technology, 1-7. https://doi.org/10.1080/10400435.2018. 1467514

Keating, E., \& Mirus, G. (2003). American sign language in virtual space: Interactions between Deaf users of computer-mediated video communication and the impact of technology on language practicers. Language in Society, 32(5), 693-714.

Kermit, P. (2006). Tegnspråk og anerkjennelsen av døve som en språklig minoritet. In S. Jørgensen \& R. Anjum (Eds.), Tegn som sprak: En antologi om tegnsprak [Signs as language: An anthology about sign language]. Oslo: Gyldendal Akademisk.

Kermit, P., Mjøen, O. M., \& Olsen, T. (2011). Safe in the hands of the interpreter? A qualitative study investigating the legal protection of Deaf people facing the criminal justice system in Norway. Disability Studies Quarterly, 31(4).

Lundström, B. (2001). Teckenspråket är grunden i vår profession: En bok om tolkyrket och om Sveriges teckenspråkstolkars förening [The sign language is the basis of our profession: A book about the interpretation and the Swedish sign language interpreter's association]. Stockholm: Sveriges teckenspråkstolkars förening.

Nexes. (2018). NEXt generation emergency services. NEXt generation Emergency Services. Retrieved from nexes.eu

Paredes, H., Fonseca, B., Cabo, M., Pereira, T., \& Fernandes, F. (2014). SOSPhone: A mobile application for emergency calls. Universal Access in the Information Society, 13(3), 277-290.

Power, M. R., Power, D., \& Horstmanshof, L. (2006). Deaf people communicating via SMS, TTY, relay service, fax, and computers in Australia. Journal of Deaf Studies and Deaf Education, 12(1), 80-92.

Raanes, E. (2013). Døve på slutten av 1800-tallet â en språklig og kulturell gruppering? Maal og Minne, 105(1).

Regeringskansliet. (2006). Teckenspråk och teckenspråkiga: Översyn av teckenspråkets ställning [Sign language and signers: Review of the sign language]. Stockholm: Fritze.

Regjeringa. (2008). St.meld. nr. 35 (2007-2008), Mål og 
meining: Ein heilskapleg norsk språkpolitikk [Goals and Meining: One holistic Norwegian language policy]. Regjeringa.no. Retrieved from www.regjeringen. no/no/dokumenter/stmeld-nr-35-2007-2008-/id519 923

Roy, C. B. (2002). The problem with definitions, descriptions, and the role methaphors of interpreters. In F. Pöchhacker \& M. Shlesinger (Eds.), The interpreting studies reader (pp. 345-353). London: Routledge.

SOS Alarm. (2017). Viktiga telefonnummer [Important phone numbers]. SOS Alarm. Retrieved from www.sosalarm.se/viktiga-telefonnummer/112/112for-tal-och-horselskadade

Svensk författningssamling. (2009). Språklag (2009:600). Sveriges Riksdag. Retrieved from www. riksdagen.se/sv/dokument-lagar/dokument/svenskforfattningssamling/spraklag-2009600_sfs-2009-600

Telenor. (2018). Produkter for hørselshemmede, synshemmede og eldre [Products for people with hearing loss, visual impairment and elderly]. Telenor ASA. Retrieved from www.telenor.no/privat/kunde service/personer_med_nedsatt_funksjonsevne

United Nations. (1948). Universal declaration of human rights. UN General Assembly.

United Nations. (2006). Convention on the rights of persons with disabilities and optional protocol. United Nations. Retrieved from www.un.org/disabilities/ documents/convention/convoptprot-e.pdf
Warnicke, C. (2017). Tolkning vid förmedlade samtal via Bildtelefoni.net: Interaktion och gemensamt meningsskapande [The interpreting of relayed calls through the service Bildtelefoni.net: Interaction and the joint construction of meaning] (Unpublished Doctoral Dissertation). Örebro University, Örebro, Sweden. Retrieved from oru.diva-portal.org/smash/ get/diva2:1089956/FULLTEXT01.pdf

Warnicke, C. (2018). The co-creation of communicative projects within the Swedish Video Relay Service (VRS). In J. Napier, R. Skinner, \& S. Braun (Eds.), Here or there: Research on interpreting via video link. Washington, DC: Gallaudet University Press.

Warnicke, C., \& Plejert, C. (2012). Turn-organisation in mediated phone interaction using Video Relay Service (VRS). Journal of Pragmatics, 44(10), 1313-1334.

Warnicke, C., \& Plejert, C. (2016). The positioning and bimodal mediation of the interpreter in a Video Relay Interpreting (VRI) service setting. Interpreting, 18(2), 198-230.

Warnicke, C., \& Plejert, C. (2018). The headset as an interactional resource in Video Relay Interpreting (VRI). Interpreting, 20(2), 285-308.

World Health Organization, \& World Bank. (2011). World report on disability. Genebra: World Health Organization. Retrieved from www.who.int/disabilities/ world_report/2011/report.pdf

\section{About the Author}

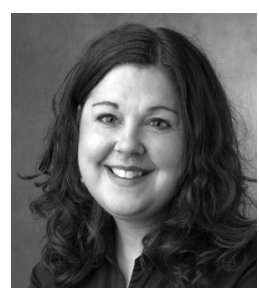

Camilla Warnicke is a PhD working at the University Health Care Research Centre (UFC), Örebro County council, Sweden. She is affiliated with the School of Health Sciences at Örebro University, Sweden. She is a certified interpreter between (spoken) Swedish and Swedish Sign Language. She also works as a trainer in the interpreter programme in Örebro, Sweden. Her research interests are related accessibility, disability studies, and interaction in interpreted encounters (spoken/signed language interpreting), particularly video relay interpreting and conversation analysis. 